\title{
OBJEKTIVIZACE PŘíSTUPU゚ K UMÍSTĚNÍ STAVEB S POUŽITÍM MATEMATICKÝCH METOD
}

\section{OBJECTIFICATION OF APPROACHES TO THE LOCATION OF BUILDINGS USING MATHEMATICAL METHODS}

\author{
Matej Bunat ${ }^{1}$ \\ ${ }^{1}$ CTU in Prague, Thakurova 2077/7, Prague 6, 160 00, Czech Republic, matej.bunat@fsv.cvut.cz
}

\begin{abstract}
Abstrakt
Investor, projektant i stavební úřad jsou subjekty, které se spolupodílejí na rozhodovacím procesu umístění staveb. Stavby Ize umístit na zelené louce, pokud se jedná o stavby nové nebo Ize využít brownfieldů, tj. nevyužitých objektů a tyto rekonstruovat, eventuálně rozšiřit, přistavět, nastavět apod.

Rozhodování je vhodné aplikovat s pomocí vícekriteriálního rozhodovacího procesu, který zahrne veškeré faktory tohoto strategického rozhodnutí. Velmi vhodným nástrojem pro rozhodování je metoda bazické varianty, která je využita $v$ rámci tohoto článku. $V$ rámci této metody se pracuje $s$ váhami, hodnocením a rizikem. Výsledkem je vyhodnocení nejvýhodnější varianty s pomocí modelování.

Uvedený model metody bazické varianty pro řešení obdobných úloh pracuje s pomocí vah věcných kritérií, kde je v článku vysvětleno hodnocení věcných kritérií včetně tabelárního zpracování a velmi detailně je také identifikováno a popsáno riziko věcných kritérií s tím, aby komparace výsledků, která vyjde ze sešitu MS Excel, měla co největší vypovídací schopnost. Výsledkem je vytvoření sešitu MS Excel pro výpočet bazické varianty pro maximálně 5 variant.
\end{abstract}

\section{Klíčová slova}

Vícekriteriální rozhodování, metoda bazické variant, brownfield, městské inženýrství

\begin{abstract}
The investor, designer and local building authority are subjects, which collaborates during the decision making process on The process of placement buildings. The civil engineer projects can be placed on greenfields, if they are new or brownfield objects, i.e. unused objects and therefore they can be recontructed, eventually expand, etc.

For the decision making process it is suitable to use Multi-criteria Decision making process which involves all the factors needed for this strategic decision. Very suitable method for the decision making is process called Base variation, which is used trough out this article. This method is based on weight of the scales, reviews and risk. The results is evaluation of the best option with help of simulation.

The demonstrated model of Base variation for solving similar tasks is based on weight of the substantive criteria, where in the article there is explained the evaluation of substantive criteria including general processing and very deeply contains the downsides of the substantive criteria so that the comparison of results, which are taken from MS Excel, are with highest assessment ability. The result is the creation of a MS Excel for calculating a Base variation for up to 5 variants.
\end{abstract}




\section{Keywords}

Multi-criteria decision-making process, brownfield, urban engineering

\section{JEL Classification}

$\mathrm{L} 74, \mathrm{R} 50, \mathrm{C} 38$

DOI: https://doi.org/10.14311/bit.2017.01.06

Editorial information: journal Business \& IT, ISSN 2570-7434, CreativeCommons license (c) (1) published by CTU in Prague, 2017, http://bit.fsv.cvut.cz/ 


\section{Úvod}

Nevyužívané, opuštěné či dokonce devastovaná území jsou v současné době velkým problémem mnoha obcí nejen v České republice, jedná se o tzv. brownfieldy.

Dle ústavu pro jazyk český1 Ize slovo „brownfield“ ve spisovné češtině znamená užívat jako nesklonný anglický tvar nebo jej Ize používat v jeho počeštěné formě se skloňováním podle mužského rodu.

Brownfieldy vznikají z mnoha př́čin, ale úzce souvisí se společensko-ekonomickými změnami ve společnosti. Problematika brownfieldů není jen problém současné doby, ale neustále plynoucím problémem. Proto je záhodné se zabývat tímto problémem.

Podkladů k této problematice vzniklo již spousta. Pokud je hodnocen prímý vztah mezi brownfieldem a městským inženýrstvím, nelze nalézt prakticky vůbec žádné informace. Městské inženýrství je multidisciplinární obor, který se zajímá o technickoekonomické problémy v sídlech stejně jako o problematiku městských staveb, občanského vybavení, moderní řizení apod.

Jedním z cílủ článku je poukázat na problém brownfieldů a jejich př́padnou revitalizací. Mělo by se totiž stát tato problematika víc populárnější a zaujmout větší povědomí veřejnosti. Jedním z hlavních důvodů, proč se zabývat problematikou je udržitelný rozvoj.

Dalším cílem práce je objektivizace rozhodovacího procesu výběru variant při výstavbě na zelené louce či na tzv. brownfieldu. Předmětem práce je navrhnout metodiku rozhodování a doporučit nástroj, kterým by bylo možné usnadnit a zobjektivnit rozhodování, protože vlastní rozhodovací proces není nástrojem, ale řadu metod Ize jako nástroje využít. Neexistuje pro takovýto účel žádná vhodná metodika, Ize jen využít řadu doporučení a zejména vzít do úvahy napojení na inženýrské sítě, dále využití těch nevhodných objektů a zkvalitnění oblasti, kde se tyto objekty nacházejí, nebot' velmi často jsou předmětem i devastace ze strany některých obyvatel.

Zároveň se zabývá obecným př́stupem měst na výstavby na zelené louce či brownfieldů.

Úvodní kapitoly, kúčelu komplexnosti př́stupu a rozhodování o umístění stavby, seznamují a vysvětlují danou tématiku.

\footnotetext{
${ }^{1}$ Dostupný online na webové stránce: http://prirucka.ujc.cas.cz/
} 


\section{Základní rozdělení ploch určených pro výstavbu}

Země se skládá ze souše a vody. A na jakémkoli povrchu je možné vystavět stavební dílo. Tento fakt potvrzují i možné rozdělení oborů na fakultě stavební Českého učení technického v Praze. Pozemní stavitelství, dopravní stavby, vodohospodářské stavby atd. Z větší části je využívána souš.

Dále pevnou zem pro výstavbu je zjednodušeně rozdělena na plochy určené pro výstavbu a místa na kterých se stavět nesmí. Tento zákaz není trvalý a je možné, že bude kdykoli v budoucnu zrušen. Nicméně nejčastějším místem, kde nelze stavět jsou pole určené pro zemědělství, lesy apod. Základním rozdělení ploch určených pro výstavbu Ize rozdělit na brownfieldy, greenfieldy a blackfieldy.

\section{Brownfield}

Brownfieldy vznikají z mnoha prríčin, ale úzce souvisí se společensko-ekonomickými změnami ve společnosti. Problematika brownfieldů není jen problém současné doby, ale neustále plynoucím problémem a bohužel tedy i problémem budoucím. Proto je záhodné se zabývat problémem brownfield.

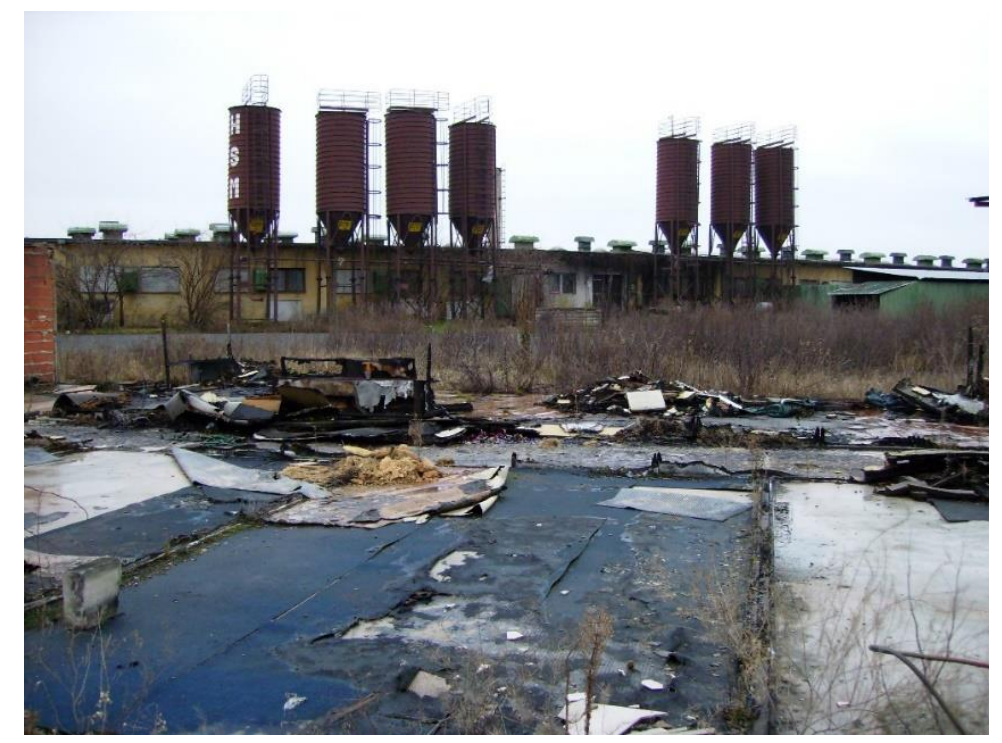

Obr. 1: Ukázka zemědělského brownfield u Jenštějna, zdroj: Wikipedie²

\section{Definice Brownfield}

Pro definici pojmu brownfield neexistuje jednotná definice, zejména kvůli tomu, že se tento pojem vyskytuje v mnoha odvětvích a každý jej chápe trochu odlišněji. Je tedy zrejmé, že si každý vytvoří svou vlastní definici přizpůsobenou ke své zkoumané problematice. Nicméně každá z definicí popisuje tentýž problém, jenž klade důraz na odlišný úhel pohledu. Pro ilustraci je uvedena definice dle Ministerstva Průmyslu a Obchodu, který se má v rámci českého státu o problematiku brownfield starat.

Dle MPO je stanovena definice jako: Brownfield je nemovitost (pozemek, objekt, areál), která je nedostatečně využívaná, zanedbaná a může být i kontaminovaná. Vzniká jako pozůstatek průmyslové, zemědělské, rezidenční, vojenské či jiné aktivity. Brownfield nelze vhodně a efektivně využívat, aniž by proběhl proces jeho regenerace. [1]

\footnotetext{
${ }^{2}$ https://cs.wikipedia.org/wiki/Brownfield
} 
Nicméně v současnosti se nejvíce uchytila definice vytvořená společností CABERNET ${ }^{3}$. Tato definice říká, že brownfieldy jsou území, která:

- jsou dotčena předchozím využití

- jsou zchátralá nebo nedostatečně využívané

- nacházejí se převážně v urbanistickém území

- potřebují určitý zákrok, pro opětovné efektivní smysluplné využití

- mohou mít také problém s kontaminací [2]

Brownfieldy Ize dělit do druhů dle jejich vzniku, viz. následující obr. č. 2:

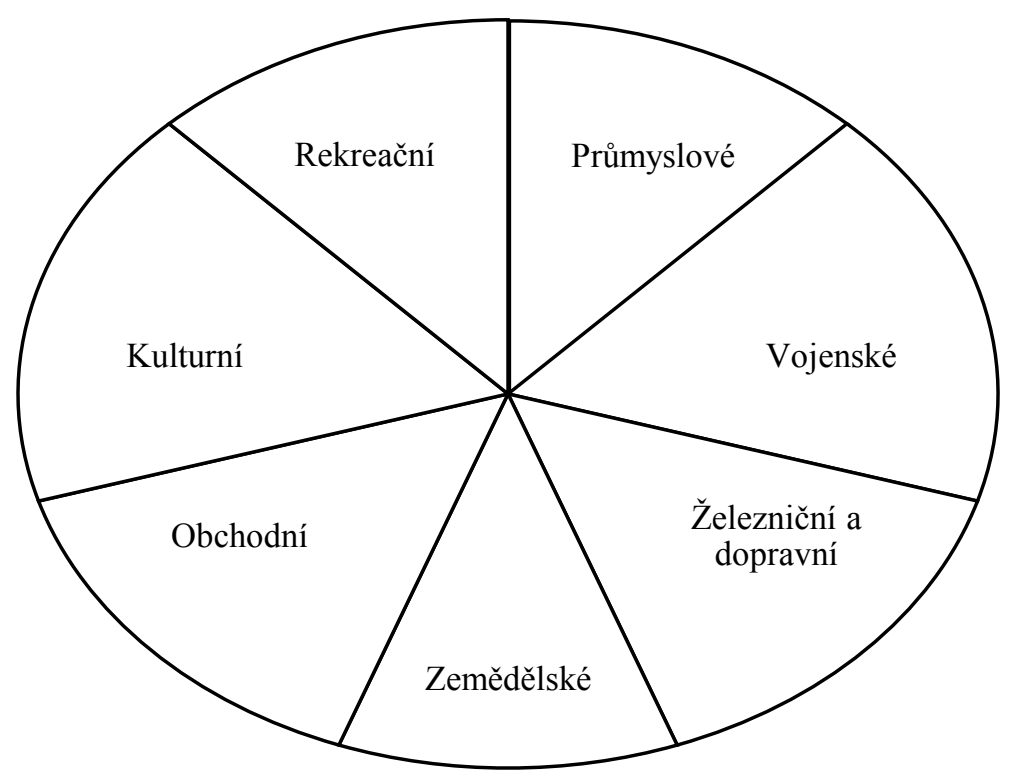

Obr. 2: Druhy brownfieldů [3], úprava vlastní

Nejčastější vzniky brownfieldů jsou z důvodu snižování těžby, průmyslovém činnosti, využití půd. Celkově snižování zemědělské činnosti vznikají další a nové nevyužité plochy.

\section{Greenfield}

Přesným opakem brownfield je greenfield. Na rozdíl od pojmu brownfieldu se v českém jazyce uchytil český překlad, zelená louka. Jedná se o urbanistický termín, který popisuje území doposud nezastavěné a je využívána jako zemědělská půda nebo dokonce ryze prírodní plochy. $Z$ hlediska životního prostředí a ekologie je nejlépe nevyužívat tyto plochy k developerským projektům. [4]

\section{Blackfield}

Blackfield, jsou lokality, které se vyznačují vysokými hodnotami kontaminace půdy, podzemních, povrchových vod či dalších složek životního prostředí. Postupuje území, jenž se nedá využívat v takové míře, kvůli těmto vysokým hodnotám kontaminace. Lze nazvat území blackfield jako nejhorší variantu obecnějšího pojmu brownfield. Zdroje znečištění těchto území byly většinou těžba a zpracování nerostných surovin, průmyslová výroba, skladování a skládkování nebezpečných odpadů, doprava a aktivity související s vojenským využitím ploch. Náklady na revitalizaci těchto míst jsou tak nákladné, že nikdo nechce tyto náklady věnovat na regenerace. Na druhou stranu ovšem odkládání revitalizace může mít negativní vliv, jak na budoucí náklady věnované do úpravy těchto území, tak také na velikost znečištěních míst.

\footnotetext{
${ }^{3}$ Concerted Action on Brownfield and Economic Regeneration Network
} 


\section{Databáze brownfield v České republice}

V České republice spravuje databázi brownfield společnost Czechinvest ${ }^{4}$, která se snaží nabízet lokality pro plány investorů, jak pro investory ciziny, tak pro české investory. Snaží se tedy pomáhat na jedné straně revitalizovat území, která již byla plně využita lidmi, kteří již toto území úplně opustili. Na druhou stranu zároveň pomáhá investorům s výběrem vhodných lokalit, které mohu zakoupit bez poplatku, jen za to, že danou lokalitu využijí. Některé lokality jsou nabízeny pouze k prodeji, jiné zase $\mathrm{k}$ pronájmu. Pro město to zároveň pomáhá $\mathrm{v}$ tom, že nebude mít nevyužité prostory, do kterých již zavedli veškeré městské inženýrství. [5]

Hlavním podkladem pro databázi brownfield byly Vyhledávací studie pro lokalizaci brownfieldů. Práce na studii trvala něco přes dva roky, financované z veřejného rozpočtu. Tu poté přebrala právě, již několikrát zmiňovaná, společnost Czechinvest, která využila studii ve spolupráci s jednotlivými krajskými úřady pro tvorbu databáze. Samozřejmě databáze není úplně kompletní, proto zavedli také možnost přidávat nové lokality, které jsou nevyužité, nebo také zátěží.

Dle společnost Czechinvest bylo najít a popsat veškerá nevyužitá či neefektivně využívaná území. Veškeré získané informace využít pro přípravy budoucích investičních záměrů a zároveň prípravy dokumentů zabývajících se řešením obnovy dané lokality. Zjištění zároveň ekologické zátěže na dané území. To zejména kvůli předpokládaných nákladů na regeneraci dané lokality.

MPO zároveň přišlo s operačním programem „Podnikání a inovace pro konkurenceschopnost" vytvořené pro období 2014-2020 s programy podpory. Celkem jich vytvořili 24 . Cílem těchto programů je, že mohou budoucí zadavatelé požádat o spolufinancování jejich podnikatelských projektů ve zpracovatelském průmyslu a souvisejících službách. Představa o výsledku těchto programů, a ve své podstatě také obecně regenerace brownfieldů, je zvýšení přitažlivosti a hodnoty jednotlivých míst, na takovou úroveň, aby mohla být schopná konkurovat tzv. zeleným polím. Dostatečná nabídka dotačních programů, zafinancována přes veřejný sektor, právě dokáží přesvědčit investory o možnosti využití nevyužitých míst, pomáhají zabezpečit financování nákladové mezery na snížení nákladů zbytečných zábor, demolice stávajících objektů apod. Podporují tím zvláště investice v oblasti podnikání, bydlení, zábavních lokalit apod. Díky tomu, že se právě budou revitalizovat území, které jsou ekologickou zátěží, na nové živé prostory, zrovna přispívá k revitalizaci území, čímž také ke zvyšování kvality životního prostředí. [5]

\footnotetext{
${ }^{4}$ Tato databáze je veřejně dostupná na webových stránkách: www.brownfieldy.cz
} 


\section{Městské inženýrství}

Městské inženýrství je relativně mladým oborem, zároveň se řadí mezi interdisciplinární obory, jinak řečeno mezioborový obor, stále hledá své nejvhodnější nástroje a postupy pro své vlastní působení a svou koncepci. Také nemá jednotnou definici, ty nejpoužívanější jsou dále definovány.

Stavitelství obecně rozdělujeme na dva hlavní celky: stavitelství pozemní a stavitelství inženýrské. Nicméně inženýrské stavby ještě Ize dále rozdělit na spoustu dílčích podoborů, např. silniční, železniční, mostní, vodní, kanalizace. Městské inženýrství ovšem nespadá do žádného dílčího prvku. Oporou architektury je pozemní stavitelství, zatímco stavba měst, jako svou oporu využívá městské inženýrství.

Architektura, urbanismus a územní plánování, tak Ize nejlépe pochopit základní prvky MI. Přičemž každý z nich je komplexním oborem, který se částečně překrývá s tím druhým. Vztahy jednotlivých kombinací variant možného spletení je těžko rozeznatelná dvojice architektura a urbanismus. Základním rozdílem je způsob využívání pracovní metody. Urbanismus používá vědu, zatímco architektura jako pracovní metodu využívá umění. Pokud však chceme pochopit rozdíl v jejich zájmu, Ize to jen těžce, protože se oba zabývají problematikou města jako celku. Vyprofiloval se další podobor, který se zabývá stejným zájmem, a to je stavba měst. [6]

\section{Definice městského inženýrství}

Dle České komory autorizovaných inženýrů a techniků ČKAIT

Zahrnuje metodiku řešení a rozhodování všech základních technických, technicko-ekonomických a technicko-ekologických problémů spojených se zajištěním provozu měst a obcí, zejména pak hledá optimální řešení cestou tvorby reálných variant řešení, jejich vyhodnocení a následným prosazením nejlepší varianty obsluhy technické infrastruktury území.

Oprávněnost či opodstatněnost fungování městského inženýrství vyplývá z požadavků praxe a je podpořena zařazením městského inženýrství jako samostatného oboru pro inženýrskou autorizaci.

Městské inženýrství, kde rozsah oboru pro autorizované inženýry je definován jako činnosti související s projektováním a realizaci staveb městského inženýrství, zejména komunikací a úprav ploch, zásobování vodou, odvodnění území, plynovody, NTL a STL a regulační stanice STL/NTL, rozvody tepla, sdružené trasy a městský mobiliár. Celková koncepce a koordinace řešení technického vybavení měst a urbanizovaných území. [7]

Dle Českého svazu stavebních inženýrů (ČsSI)

Na počátku devadesátých let dvacátého století byl Českým svazem stavebních inženýrů definován pojem městské inženýrství a po následné aktualizaci Ize použit tuto definici: Městské inženýrství predstavuje mezioborový okruh poznatků a metod pro aktivní tvorbu koordinaci řešení koncepce technické infrastruktury území a koordinaci jejího řešení s ostatními složkami a činnostmi v území (územní plánování, ekologie území apod.). Svým spolupůsobením v rovnocenném partnerství s klasickým urbanismem garantuje a kontroluje kvalitní technickou funkci území a jeho další rozvoj. [7]

Technická infrastruktura zahrnuje technické vybavení (zásobování vodou, v zásobování energiemi, kanalizace včetně čištění odpadních vod, spoje, opatření proti škodlivým účinkům přírody, odstraňování odpadů, městský mobiliář, údržba zeleně, čištění ploch apod.) a pozemní a místní komunikace. [7]]

\section{Úloha městského inženýrství}

Úloha městského inženýrství úzce souvisí s pojmem urbanismus. Klasický urbanismus je obor, jehož výsledkem je utvářet a rozvíjet sídelní útvary (města, vesnice) jako funkční a harmonické celky. Využívá k tomu navrhování celých sídel, jejich částí a navazujících částí krajiny, včetně krajinné architektury. Jedna z možných důležitých složek městského inženýrství je územní plánování. [8] 
Městské inženýrství obsahuje metodiku řešení a rozhodování všech základních technických, technicko-ekonomických a technicko-ekologických problémů spojených se zajištěním provozu měst a obcí, zároveň odpovídá za koordinaci technického vybavení území.

Technické vybavení území (TVÚ) je základním kamenem městského inženýrství. Byly pochopeny výhody plánování takového rozměru, zejména rozvoje dané obce. To znamená pozemní komunikace, inženýrské sítě, systémy odstraňování tuhých odpadů, systémy monitoringu čistoty ovzduší aj. Staly se zcela nepostradatelnými pro fungování urbanizovaného území a pro jeho další budoucí rozvoj. Plán TVú musí být v největší míře objektivní, homogenní, efektivní, dostatečně operativní a adekvátní pro budoucí rozhodování o obci, a to zejména kvůli plné kompetentnosti celého plánu. Tento elaborát musí být sepsán, schválen a uplatněn včas a $v$ takovém rozsahu, aby uspokojil veškeré požadavky na obsluhu území. Jak již bylo řečeno v úvodu, tak městské inženýrství je mladý obor, který je interdisciplinární, tak stále hledá ty nejvhodnější postupy pro použití.

Současná zaostalost a zanedbanost mnoha územních celků technické obsluhy vytváŕí kritickou hrozbu pro základní fungování jednotlivých měst a obcí. Současná situace a schopností rešení této situaci v praxi je možné nazvat nákladově a technicky neekonomickou improvizaci. Zejména vzhledem k stavu inženýrských sítí, Ize říci, že se jedná o těžce realizovatelný projekt v krátkém časovém období. Východiskem může být zejména spolehlivé zabezpečení udržení současné TVú, bez větších výkyvů a zabezpečení efektivní obnovy, modernizace a kompletace TVÚ a zabezpečení v trvale udržitelném stavu. Zaměřit se zejména na opravy a údržby současných TVÚ, než instalace nových.

Správně zavedená implementace jednotlivých bodů městského inženýrství v území má příznivé podmínky pro obyvatele sídel, zároveň může alespoň minimalizovat negativní ekologické dopady. [7]

Nové trendy v rozvoji městského inženýrství a urbanismu Ize nelézt např. ve vyspělých státech zprostředkováním iniciativy EFUC (European Forum on Underground Construction). Městské inženýrství je v České republice zajištováno především přes organice ČKAIT a ČSSI, jak již bylo řečeno $v$ úvodu, i když každá z organizací chápe tento pojem trochu rozdílněji.

Základní odvětví městského inženýrství je rozděleno následovně:

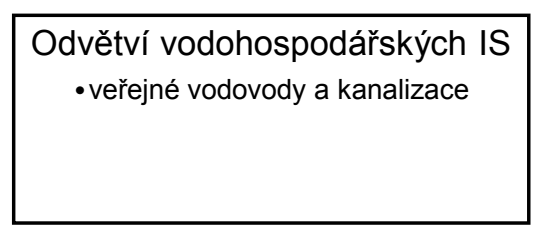

Odvětví energetických IS

- sítě pro výrobu, přenos a rozvod elektrické energie, sítě plynovodních a

sítě centralizovaného zásobování teplem a teplou užitkovou vodou

\section{Odvětví telekomunikačních sítí}
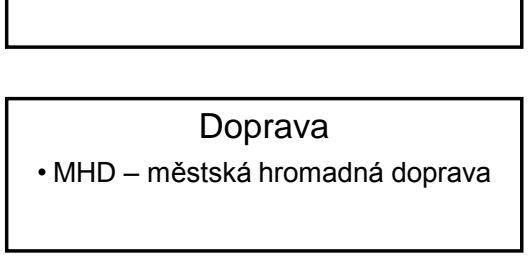

Péče o veřejnou zeleň

\section{Výstavba nových komunikacích}

Technická správa komunikací - obnova, údržba, úklid

Veřejné osvětlení

Obr. 3: Základní odvětví městského inženýrství, zdroj: vlastní 


\section{Př́stupy ke stanovení finančních úspor v rámci města}

Stanovení nákladů města pro budoucí developeský projekt se odvíjí právě od situace v rámci městského inženýrství a to při využití již stávajícího systému v kontextu využití zmiňovaných brownfieldů.

Umístění záměru investora do objektu stávajícího brownfield, či umístění stavby na tzv. zelené louce, ve většině př́padů na okraji města, s sebou přináší řadu vyvolaných investičních i provozních nákladů z městského rozpočtu.

Posouzení je nezbytné v těchto oblastech:

a) odvětví vodohospodářských IS (odvětví veřejných vodovodů a kanalizací),

b) odvětví energetických IS (odvětví sítí, výroby, přenosu a rozvodu elektrické energie, sítí plynovodních a sítí centralizovaného zásobování teplem a teplou užitkovou vodou),

c) odvětví telekomunikačních sítí

d) výstavba nových komunikacích

e) Doprava - městská hromadná doprava

f) Technická správa komunikací: obnova, údržba, úklid

g) Péče o veřejnou zeleň

h) Veřejné osvětlení

i) Další

Výše uvedené oblasti Ize graficky vyjádřit v podobě následujících schémat viz. Obr. 4: Potenciální odhad porovnání nákladů městského inženýrství při využití brownfield a greenfield pro jednotlivé funkční celky zdroj: vlastní, kde levý sektor vyjadřuje stávající stav a pravý sektor umístění stavby na nové lokalitě. Ke schématům je nutno doplnit, že výše nákladů naznačených sloupcových grafů je pouze ilustrativní a svislá osa y v každém schématu ukazuje stávající výši nákladů čerpaných v rámci městského rozpočtu. Nelze tedy hovořit o absolutní výši vyjádřené v korunách, ale pouze o myšlenkové pojetí.

Naproti tomu pravý sloupec ukazuje nezbytné zvýšené náklady z rozpočtu města na vybudování nové komunikace ke stavbě, zvýšení budoucího nároku na údržbu zeleně atd.

Taktéž tento pravý sloupec nevyjadřuje ve svém navýšení nákladů faktické náklady v Kč. Ale pouze modelové pojetí budoucího zatížení rozpočtu města. 


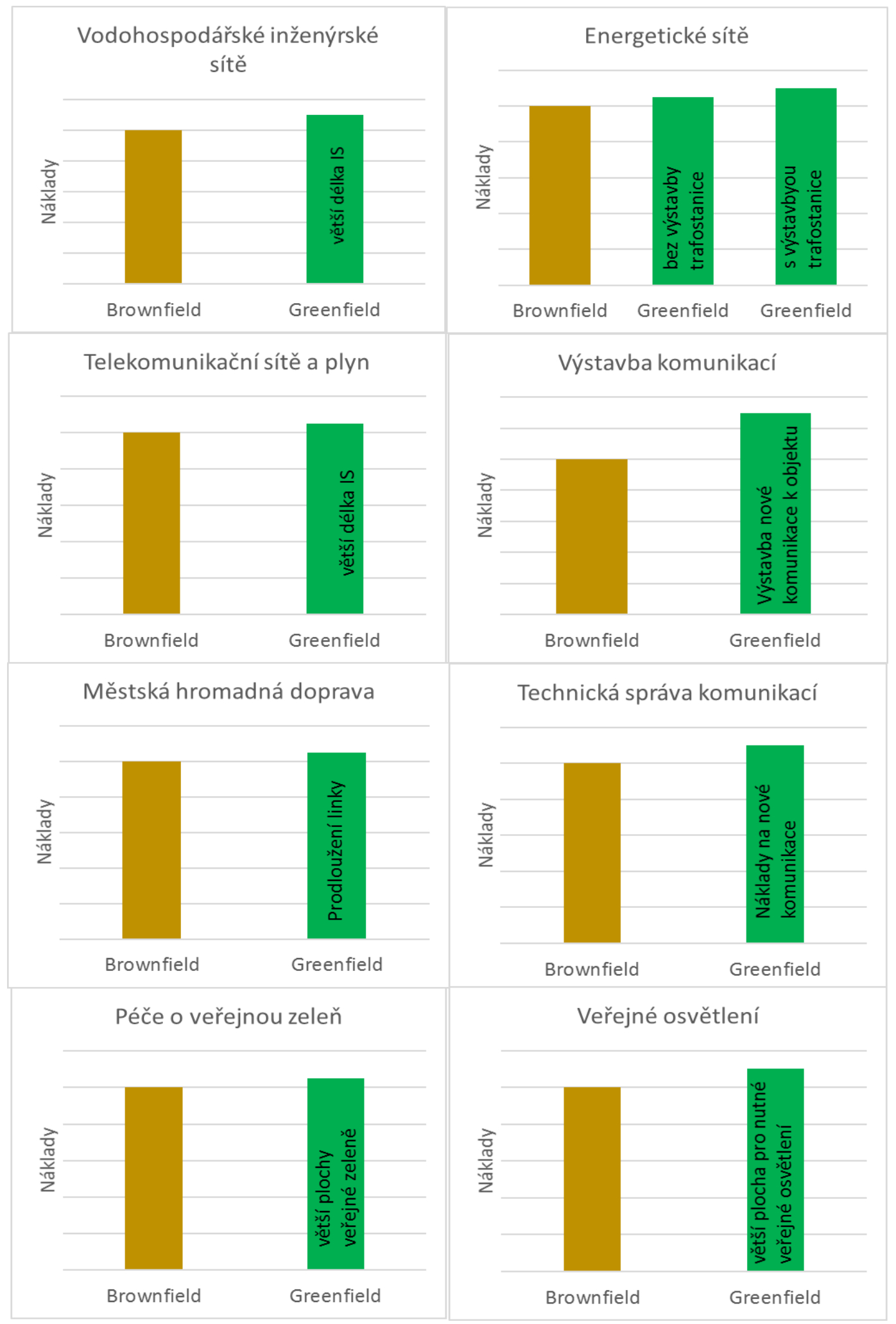

Obr. 4: Potenciální odhad porovnání nákladů městského inženýrství při využití brownfield a greenfield pro jednotlivé funkční celky zdroj: vlastní

Pro každý sektor, který souvisí se zvýšenými náklady na umístění stavby do nové lokality, na tzv. zelenou louku, přináší městu jednoznačně zvýšené náklady oproti brownfield, a to ve dvou pohledech:

1) vybudováním nové komunikace k lokalitě, zavedením MHD, a dále viz obrázky výše,

2) současně též i zvýšené náklady budoucí ve formě obnovy a údržby. 
Významným kritériem je také eliminace současného nevyhovujícího stavu brownfieldu a zatraktivnění jeho novým využitím v oblasti, kde se brownfieldy nachází.

Finanční vyjádření těchto nákladů v obou blocích by bylo předmětem detailního výpočtu pro každý konkrétní brownfield, a pro každou novou stavbu na zelené louce, s totožným plněním funkce.

Městští urbanisté a architekti musí ve spolupráci se stavebními odbory akceptovat tyto dopady a vyvíjet tlak na investory, aby více využívali územní celky, brownfieldy.

Vědecký př́nos tohoto rozkladu je obecným návodem pro rozhodování a k jeho naplnění nelze pohližet jen z pohledu nákladů, ale celkové koncepce města, jeho intravilánu, jeho architektonické hodnoty okolních staveb a řady dalších faktorů.

Rozhodně je nezbytné každé posouzení využití brownfieldu posoudit moderními rozhodovacími metodami, jako např. brainstorming, bodovací metody.

\section{Výběr lokality}

V předinvestiční fázi neboli fázi rozhodovací, je nejdůležitější část najít správnou lokalitu, kam situovat nový výstavbový projekt. Pro každou stavbu jsou určeny jiné parametry, kterým se věnujeme, a taky mají jinou váhu důležitosti. To zejména kvůli náročnosti, návštěvnosti, nákladnosti, dostupnosti a dalších subjektů. Tím nejdůležitějším, proč se tolik zabíráme výběrem lokality je, abychom posoudili jeho vhodnost z hlediska dosažení, pokud možno maximalizaci, užitků. Jinak řečeno, splnit veškeré stanovené cíle projektu. [9]

Proces výběru nejvhodnější varianty je stejně důležitý a probíhá v přibližně stejném rytmu v České republice i v ostatních vyspělých zemí.

Průběh rozhodovacího procesu výběru varianty Ize rozdělit do následujících bodů:

1. Analýza představ a požadavků

2. Analýza současného stavu a věcných kritérií rozhodovacího procesu, s možnou tvorbou stromu kritérii ${ }^{5}$

3. Použití metody pro porovnání, např. Metoda bazické varianty

4. Výběr nejvhodnější varianty

Toto základní rozdělení lze ještě blíže specifikovat a rozdělit na menší celky, viz. Obr. 4.

\footnotetext{
${ }^{5}$ Strom kritérií graficky zobrazuje jednotlivé vazby a vztahy mezi kritérii.
} 


\section{Rozhodovací proces}

Je velmi úzce spojen s pojmem subjektivní posuzování, protože výběr je vždy do určité míry subjektivní. Každý člověk si vždy vytvoří emoci a objektivně úplně vybírat neumí. Velmi často se používá subjektivní názor a posouzení dané problematiky, dle osoby, která danou studii vytváří. Nejdůležitějším bodem u rozhodování více nabídek, možných projektů, o stanovení objektivních kritérií, které budou brány v potaz. Je nezbytné porovnávat vždy stejná porovnatelná kritéria, aby bylo možné z co největší pravděpodobností objektivně rozhodnout, protože téměř vždy je odpověd' na každé kritérium subjektivní, zejména ze strany estetiky.

\section{ROZHODOVACÍ PROCES}

Výzkum spočívá v analyzování rozhodovacího procesu při výběru pořizování staveb na zelené louce, potenciálně na tzv. brownfieldech. Cílem je zmapovat a definovat rozhodovací procesy, tak aby byl model co možná nejvíce objektivní a došlo k objektivizace rozhodování.

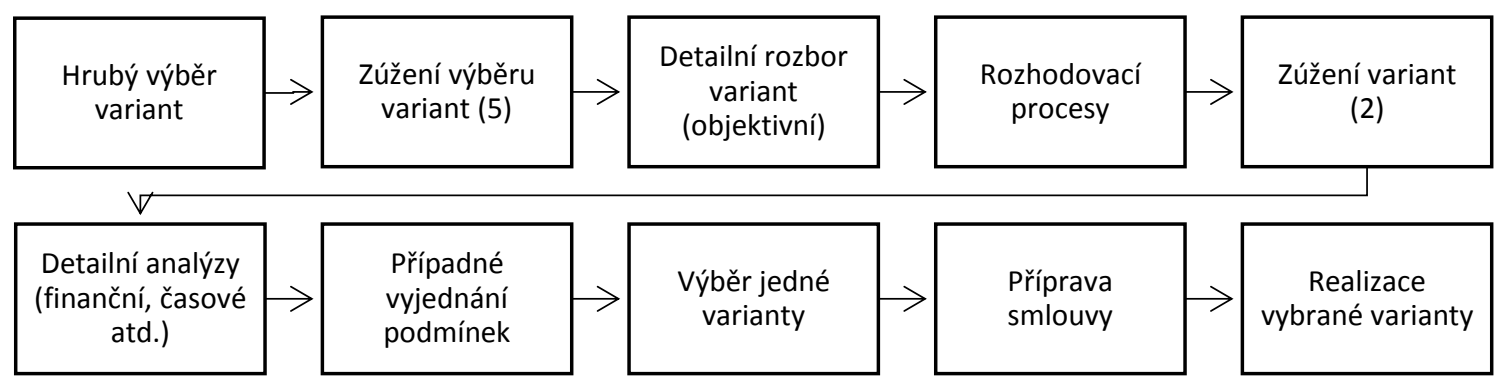

Obr. 5: Obecný postup rozhodovacího procesu, zdroj: vlastní

Hrubý výběr variant je začáteční bod, v tomto bodě je vyfiltrován veškerý počet možností, které mohou splňovat požadavky rozhodovatele, investora. Poté dochází k zúžení variant, které splňují základní kritéria na cca 5 možných variant. Pro těchto 5 variant se vytvoří objektivní hodnocení nabídek neboli detailní rozbor. Poté opět dochází k zúžení variant, nejčastěji na 2 potenciální varianty. Pro ně se vytvoří analýzy, které určí jejich efektivnost podrobněji. Zároveň je ještě možné s ostatními stranami obchodního vztahu vyjednávat změny, podmínky, pro byznys. Nakonec je vybrána jedna výsledná varianta, která bude realizována.

Každé zúžení výběru variant je nejdůležitějším bodem rozhodovacího procesu jako celku. Lze jej rozdělit na několik dílčích prvků: definování kritérií, strom kritérií, určení vah jednotlivých kritérií, vytvořit data které lze dále využívat při porovnání v metodě pro posuzování procesů. Pro úspěšnost výběru je velmi důležitá poslední část a tou je interpretace výsledků v takové kvalitě, aby bylo jasné, proč byla vybrána právě tato.

Identifikování kritérií:

Každá varianta má nespočet charakteristik, proto je nezbytné vytvořit takový počet kritérií pro posuzování, které jsou porovnatelné pro všechny varianty. $Z$ toho Ize následně určit pohledy, jak na daný projekt nahlížet. Každá varianta nabízí určité kvality, služby, rychlost výstavby, ekonomickou efektivnost, budoucí zisk apod. Proto se určují základní pohledy, kritéria, která budou ve výsledku určovat rozhodovací proces.

Kritéria Ize rozdělit do dvou podmnožin, globální a věcná. Globální kritéria jsou taková kritéria, která sdružují jednotlivá kritéria se tejnou věcnou povahou. Zatímco věcná kritéria jsou kritéria, které Ize exaktně popsat. [10]

Globální kritéria nelze využít u metody bazické varianty, pouze u metody pomocí softwaru PREV. I přesto je dobré začít popisem globálních, protože se poté dochází k popisu věcných kritérií. 
Věcná kritéria vytváří podmnožiny globálních kritérií. Jinými slovy se jedná o detailnější charakterizaci jednotlivých globálních kritérií. Věcná kritéria na rozdíl od globálních prímo popisují kritéria na základě přímých popisů a konkretizaci. Věcná kritéria vždy rozvíjí každé globální hledisko a jsou přímo vázána na něj. Pro ilustraci vybráno jedno globální kritérium s rozpisem možných věcných kritérí́.

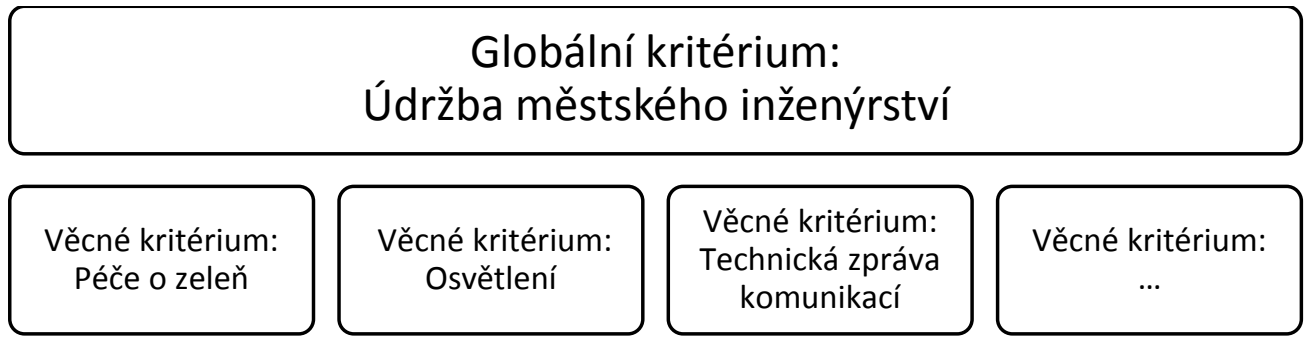

Obr. 6: Obecný postup rozhodovacího procesu, zdroj: vlastní

\section{Metody rozhodování}

\section{Metody pro určení důležitosti (vah)}

Poté co jsou identifikována kritéria, globální či věcná, je nezbytné určit i jejich důležitost pro výběr. Existuje spousta možností, jak dodat kritériím důležitost je spousta. Pro ilustraci jsou uvedeny dvě nejčastější metody, bodovací metoda a metoda postupného rozvrhu vah.

\section{Bodovací metoda}

Bodovací metoda je jednoduchý způsob, jak určit váhy kritérií. $K$ jednotlivým kritériím, se přiřazují dohodnuté počty bodů $b_{j}$, tak že počet bodů kritéria je podělen celkovým počtem bodů všech kritérií. A zároveň je určen maximální počet bodů, který získá nejdůležitější kritérium. Toto je vystiženo ve vztahu:

$$
v_{j}=\frac{b_{j}}{\sum_{j=1}^{n} b_{j}}
$$

Kde:

$v$... váha j-tého kritéria a $b$ je počet bodů j-tého kritéria.

Jednou z možných konkretizací využití bodovací metody je metoda alokace 100 bodů. $U$ této metody má hodnotitel k dispozici 100 bodů, které má rozdělit mezi jednotlivá kritéria v souladu s významností jednotlivých kritérií. Lze si 100 bodů predstavit také jako procentuální hodnotu (100\%). Váha jednotlivého kritéria je představena hodnotou mezi 0 až 100. Přičemž je nezbytné, aby součet všech vah kritérií dal 100. Tato metoda je využívána v přiložené aplikaci MS Excel pro výpočet bazické varianty. [11]

\section{Metoda Postupného rozvrhu vah}

Metoda postupného rozvrhu vah se používá tak, že je soubor kritérií rozdělen do skupin, považovaných za agregovaná nadřazená kritéria. Těmto globálním kritériím, které v sobě skrývají veškerá věcná kritéria, jsou stanovené váhy. Výsledná váha jednotlivých kritérií se zjistí jako součin relativních vah těchto kritérií a váhy odpovídající skupiny, do které kritérium náleží. [12]

Postup:

- Rozdělení kritérií do souborů,

- Stanovení vah globální kritérií, včetně stanovení vah věcných kritérií

- Výpočet výsledné váhy kritéria (součin relativní vah těchto kritérií a váhy odpovídající skupiny, do které kritérium náleží) 


\section{Metoda bazické varianty}

Metoda vyjadřuje poměr naplnění hodnocení ku nejlepší hodnotě (etalonu). Tato metoda využívá dílčí hodnocení jednotlivých variant, stím, že jednotlivé varianty v rámci určitého kritéria se porovnávají s hodnotou, bazickou variantou, která je vztažena k tomu kritériu. Stanoví se reprezentant, hodnota bazické varianty, pomocí ním indexy, reprezentující míra splnění každého konkrétního věcného, kvalitativního, kritéria a vyhodnocení nejvhodnější varianty. Výběr nejvhodnější varianty je podstata metody bazické varianty. [12]

$H^{j}=\sum_{i=1}^{n} v_{i} k_{i j}$

Kde:

$H^{j}$... celková hodnota j-té varianty,

$v_{i} \ldots$ váha i-tého kritéria,

$k_{i j} \ldots$ koeficient vyjadřující poměr hodnoty kritéria $\mathrm{k}$ hodnotě etalonu (bazická varianta, požadované hodnoty, nejlepší hodnoty apod.). Výpočet koeficientu dle vzorce (2) nebo (3).

Při výpočtu koeficientu je nutné rozlišovat kritéria z pohledu preferencí, a to rozlišení na kritéria $s$ rostoucí nebo klesající preferencí (výnosová nebo nákladová). Podle druhu preference se pak zvolí vzorec pro výpočet tohoto koeficientu.

Rostoucí preferencí:

$k_{i j}=\frac{x_{i j}}{\text { etalon } x_{i j}}$

Klesající preference:

$k_{i j}=\frac{\text { etalon } x_{i j}}{x_{i j}}$

Pro usnadnění je přiložen k článku MS Excel, ve kterém je přednastaven výpočet bazické varianty. Jedná se o univerzální excel a je možné aj přednastavit pro konkrétní účely kohokoli.

Pro schnutí, metoda pracuje se skutečnými hodnotami kvalitativních věcných kritérií. A hodnot, jak se daná skutečná hodnota kritéria dané varianty odklání od hodnoty bazické varianty. Porovnávají se u každé varianty vždy každé věcné kritérium zvlášt́ mezi sebou, nikoliv všechny kritéria dohromady. Až součtem jednotlivých výsledných koeficientů bude stanoveno výsledné hodnocení a až výsledné koeficienty porovnáme pro výběr nejvhodnější varianty. [12]

\section{PREV}

Zatímco výpočet bazické varianty je rozhodovací proces výhradně deterministický, tak lze využít i pro rozhodování i stochastický přístup, a to například pomocí softwaru PREV v 2.0., vytvořený na katedře ekonomiky a managementu ve stavebnictví na škole Českého vysokého učení v Praze. $V$ této práci je využíván pouze deterministický přístup. [13]

\section{Vlastní výpočet porovnání variant}

Byly vybrány celkem 2 varianty, výstavba na zelené louce a brownfield. Kde je obecně, ilustrativně, ukázán rozdíl pro výstavbu na zelené louce a brownfieldu. Nelze hovořit o absolutních výší jednotlivých ohodnocení kritérií vyjádřené v měrných jednotkách, ale pouze o myšlenkové pojetí.

\section{Definování globálních a věcných kritérií:}

Při řešení nové výstavby na zelených loukách nebo brownfield byla zvolena následující podstatná kritéria. Tyto kritéria byla zvolena na základně základních nejčastějších problémových partií, 
vyplívajících též z kapitoly Přístupy ke stanovení finančních úspor v rámci města, při zakládání nové stavby. Jedná se o obecné rozčlenění kritérií pro rozhodování z výběru variant.

- Doprava

- Občanská vybavenost

- Stavební vlastní objektu,

- Vodohospodářská infrastruktura

- Energetická infrastruktura

- Telekomunikační sítě

- Údržba městského inženýrství (MI)

Poté jsou stanovena věcná kritéria, která vytvárí podmnožiny globálních kritérií. A byla stanovena takto:

Tab. 1: Identifikace globálních a věcných kritérií. zdroj: vlastní

\begin{tabular}{|c|c|c|}
\hline Globální kritérium & Věcné kritérium & Popis kritéria / Identifikace kritérií \\
\hline \multirow{3}{*}{ Doprava } & Komunikace & Vzdálenost od stávající komunikace, kvůli nutné nové výstavbě \\
\hline & MHD & Vzdálenost od zastávky MHD -> nutná nová linka \\
\hline & parkování & Je potřeba vytvářet nová obecní parkovací místa? \\
\hline \multirow{4}{*}{ Občanská vybavenost } & Potraviny & Vzdálenost od občanské vybavenosti - potraviny \\
\hline & Banky & Vzdálenost od občanské vybavenosti - banky \\
\hline & Pošta & Vzdálenost od občanské vybavenosti - pošty \\
\hline & Pohostinství & Vzdálenost od občanské vybavenosti - pohostinství \\
\hline \multirow{2}{*}{ Stavební vlastnost objektu } & Novostavba & Bude nový výstavbový projekt novostavba? \\
\hline & Rekontrukce & Bude nový výstavbový projekt realizován jako rekonstrukce či demolice objektu? \\
\hline \multirow{2}{*}{ Vodohospodářská infrastruktura } & Vodovod & Vzdálenost od existujícího vodovodního řadu (výstavba nového vod. řadu) \\
\hline & Kanalizace & Vzdálenost od existujícího kanalizačního řadu (výstavba nového kan. řadu) \\
\hline \multirow{3}{*}{ Energetická infrastrukturae } & Energetické sítě & Vzdálenost od existující energetické sítě (výstavba nové) \\
\hline & Plyn & Vzdálenost od existující plynové přípojky (výstavba nové) \\
\hline & Teplá voda & Výstavba a provoz pro novou dodávku teplé vody do dalších objektů \\
\hline Telekomunikační sítě & Telekomukace & Vzdálenost od existující telekomunikační sítě (výstavba nové) \\
\hline \multirow{3}{*}{ Údržba MI } & Péče o zeleň & Výsadba nové zeleně a posléze její údržba \\
\hline & Osvětlení & Výstavba nového veřejného osvětlení a její provoz \\
\hline & Technická zpráva komunikací & Údržba a obnova komunikací, které vznikly nad rámec již existujících \\
\hline
\end{tabular}

\section{Využití metody bazické varianty}

Modeluje se pouze s věcnými kritérii. Pro každé kritérium se určí váha. V tomto případě byla použita metoda alokace 100 bodů.

Je nezbytné pohlížet na projekt ze dvou stran, z pohledu investora a z pohledu města.

Stanovení vah pro město bylo vytvořeno v závislosti na potenciální výši nákladů na vybudování nové infrastruktury viz. Tab. 2. A zároveň pro ilustraci uvedeny teoretické měrné jednotky jednotlivých kritérií pro každou z variant zvlášt'. 
Tab. 2: Určení vah a měrných jednotek (MJ věcných kritérií. zdroj: vlastní

\begin{tabular}{|c|c|c|c|c|c|c|c|c|}
\hline \multirow{2}{*}{ Globální kritérium } & \multirow{2}{*}{ Označení } & \multirow{2}{*}{ Věcné kritérium } & \multirow{2}{*}{ Jednotka } & \multirow{2}{*}{$\begin{array}{l}\text { Stanovení vah z } \\
\text { pohledu města }\end{array}$} & \multirow{2}{*}{$\begin{array}{c}\text { Stanovení vah z } \\
\text { pohledu investora }\end{array}$} & \multirow{2}{*}{\begin{tabular}{c|} 
Nákladové / \\
výnosové
\end{tabular}} & \multicolumn{2}{|c|}{ Skutečné MJ variant } \\
\hline & & & & & & & \begin{tabular}{|l|l|} 
Varianta A & \\
\end{tabular} & Varianta B \\
\hline \multirow{3}{*}{ Doprava } & 1.1. & Komunikace & $\mathrm{m}$ & $15 \%$ & $1 \%$ & 0 & 0 & 200 \\
\hline & 1.2. & MHD & $\mathrm{m}$ & $7 \%$ & $2 \%$ & 0 & 20 & 200 \\
\hline & 1.3. & parkování & - & $3 \%$ & $3 \%$ & 1 & 1 & 0 \\
\hline \multirow{4}{*}{ Občanská vybavenost } & 2.1. & Potraviny & $\mathrm{m}$ & $5 \%$ & $5 \%$ & 0 & 5 & 50 \\
\hline & 2.2 . & Banky & $\mathrm{m}$ & $5 \%$ & $5 \%$ & 0 & 5 & 50 \\
\hline & 2.3. & Pošta & $\mathrm{m}$ & $5 \%$ & $5 \%$ & 0 & 5 & 50 \\
\hline & 2.4. & Pohostinství & $\mathrm{m}$ & $5 \%$ & $5 \%$ & 0 & 5 & 50 \\
\hline \multirow{2}{*}{ Stavební vlastnost objektu } & 3.1. & Novostavba & - & $5 \%$ & $50 \%$ & 1 & 0 & 1 \\
\hline & 3.2 . & Rekontrukce & - & $7 \%$ & $15 \%$ & 1 & 1 & 0 \\
\hline \multirow{2}{*}{ Vodohospodářská infrastruktura } & 4.1. & Vodovod & $\mathrm{m}$ & $5 \%$ & $1 \%$ & 0 & 0 & 5 \\
\hline & 4.2. & Kanalizace & $\mathrm{m}$ & $5 \%$ & $1 \%$ & 0 & 0 & 5 \\
\hline \multirow{3}{*}{ Energetická infrastrukturae } & 5.1. & Energetické sítě & $\mathrm{m}$ & $5 \%$ & $1 \%$ & 0 & 0 & 5 \\
\hline & 5.2 . & Plyn & $\mathrm{m}$ & $5 \%$ & $1 \%$ & 0 & 0 & 5 \\
\hline & 5.3. & Teplá voda & $\mathrm{m}$ & $3 \%$ & $1 \%$ & 0 & 0 & 5 \\
\hline Telekomunikační sítě & 6.1. & Telekomukace & $\mathrm{m}$ & $2 \%$ & $1 \%$ & 0 & 0 & 5 \\
\hline \multirow{4}{*}{ Údržba MI } & 7.1. & Péče o zeleň & $\mathrm{m}^{2}$ & $6 \%$ & $1 \%$ & 0 & 0 & 20 \\
\hline & 7.2 . & Osvětlení & kus & $5 \%$ & $1 \%$ & 0 & 0 & 20 \\
\hline & 7.3. & Technická zpráva komunikací & $\mathrm{m}^{2}$ & $7 \%$ & $1 \%$ & 0 & 0 & 5 \\
\hline & & & & $100 \%$ & $100 \%$ & & & \\
\hline
\end{tabular}

Dle obecného postupu, interpretovaného v kapitole 0 , byl vytvořen MS Excel s automatickým výpočtem pro až 5 variant. $V$ tomto prípadě bylo porovnány pouze 2 varianty, viz. Tab. 3 .

Tab.3: Výpočet bazické varianty z pohledu města. zdroj: vlastní

\begin{tabular}{|c|c|c|c|c|c|c|c|c|c|c|c|}
\hline \multirow{2}{*}{ Označení } & \multirow{2}{*}{ Věcné kritérium } & \multirow{2}{*}{ Jednotka } & \multirow{2}{*}{\begin{tabular}{|c|} 
Stanovení vah \\
$100 \%$ \\
\end{tabular}} & \multirow{2}{*}{$X \operatorname{var} A$} & \multirow{2}{*}{$X$ var B } & \multirow{2}{*}{\begin{tabular}{|l|} 
Nákladové \\
/výnosové
\end{tabular}} & \multirow{2}{*}{ etalon } & \multirow{2}{*}{$\mathrm{K} \operatorname{var} \mathrm{A}$} & \multirow{2}{*}{$\mathrm{K}$ var $\mathrm{B}$} & $H$ var $A$ & \multirow{2}{*}{$\begin{array}{c}\text { H var B } \\
0,077\end{array}$} \\
\hline & & & & & & & & & & 0,95 & \\
\hline 1.1. & Komunikace & $\mathrm{m}$ & 0,15 & 0 & 200 & 0 & 0 & 1 & 0 & 0,15 & 0 \\
\hline 1.2 . & MHD & $\mathrm{m}$ & 0,07 & 20 & 200 & 0 & 20 & 1 & 0,1 & 0,07 & 0,007 \\
\hline 1.3. & parkování & - & 0,05 & 1 & 0 & 1 & 1 & 1 & 0 & 0,05 & 0 \\
\hline 2.1. & Potraviny & $\mathrm{m}$ & 0,05 & 5 & 50 & 0 & 5 & 1 & 0,1 & 0,05 & 0,005 \\
\hline 2.2 . & Banky & $\mathrm{m}$ & 0,05 & 5 & 50 & 0 & 5 & 1 & 0,1 & 0,05 & 0,005 \\
\hline 2.3. & Pošta & $\mathrm{m}$ & 0,05 & 5 & 50 & 0 & 5 & 1 & 0,1 & 0,05 & 0,005 \\
\hline 2.4. & Pohostinství & $\mathrm{m}$ & 0,05 & 5 & 50 & 0 & 5 & 1 & 0,1 & 0,05 & 0,005 \\
\hline 3.1. & Novostavba & - & 0,05 & 0 & 1 & 1 & 1 & 0 & 1 & 0 & 0,05 \\
\hline 3.2. & Rekontrukce & - & 0,07 & 1 & 0 & 1 & 1 & 1 & 0 & 0,07 & 0 \\
\hline 4.1. & Vodovod & $m$ & 0,05 & 0 & 5 & 0 & 0 & 1 & 0 & 0,05 & 0 \\
\hline 4.2 . & Kanalizace & $m$ & 0,05 & 0 & 5 & 0 & 0 & 1 & 0 & 0,05 & 0 \\
\hline 5.1. & Energetické sítě & $\mathrm{m}$ & 0,045 & 0 & 5 & 0 & 0 & 1 & 0 & 0,045 & 0 \\
\hline 5.2 . & Plyn & $\mathrm{m}$ & 0,045 & 0 & 5 & 0 & 0 & 1 & 0 & 0,045 & 0 \\
\hline 5.3. & Teplá voda & $\mathrm{m}$ & 0,03 & 0 & 5 & 0 & 0 & 1 & 0 & 0,03 & 0 \\
\hline 6.1. & Telekomukace & $\mathrm{m}$ & 0,02 & 0 & 5 & 0 & 0 & 1 & 0 & 0,02 & 0 \\
\hline 7.1. & Péče o zeleň & $\mathrm{m} 2$ & 0,055 & 0 & 20 & 0 & 0 & 1 & 0 & 0,055 & 0 \\
\hline 7.2 . & Osvětlení & kus & 0,05 & 0 & 20 & 0 & 0 & 1 & 0 & 0,05 & 0 \\
\hline 7.3. & Technická zpráva komunikací & $\mathrm{m} 2$ & 0,065 & 0 & 5 & 0 & 0 & 1 & 0 & 0,065 & 0 \\
\hline
\end{tabular}

Z druhé strany je na každý výstavbový projekt pohliženo ze strany investora. Ten má odlišný cíl od města. Tím je efektivnost projektu, nejčastěji ekonomická efektivnost, a proto byla vytvořeny váhy kritérií odlišně od vah interpretovaných z pohledu města dle Tab. 2. Výpočet výběru varianty pro investora Ize názorně vidět v Tab.4. 
Tab.4: Výpočet bazické varianty z pohledu investora. zdroj: vlastní

\begin{tabular}{|c|c|c|c|c|c|c|c|c|c|c|c|}
\hline \multirow{2}{*}{ Označení } & \multirow{2}{*}{ Věcné kritérium } & \multirow{2}{*}{ Jednotka } & \multirow{2}{*}{\begin{tabular}{|c|} 
Stanovení vah \\
$100 \%$
\end{tabular}} & \multirow{2}{*}{$X$ var A } & \multirow{2}{*}{$X$ var B } & \multirow{2}{*}{\begin{tabular}{|l|} 
Nákladové \\
/výnosové
\end{tabular}} & \multirow{2}{*}{ etalon } & \multirow{2}{*}{$K \operatorname{var} A$} & \multirow{2}{*}{ K var B } & $H$ var $A$ & \multirow{2}{*}{$\begin{array}{c}\text { H var B } \\
0,522 \\
\end{array}$} \\
\hline & & & & & & & & & & 0,5 & \\
\hline 1.1. & Komunikace & $\mathrm{m}$ & 0,01 & 0 & 200 & 0 & 0 & 1 & 0 & 0,01 & 0 \\
\hline 1.2. & MHD & $\mathrm{m}$ & 0,02 & 20 & 200 & 0 & 20 & 1 & 0,1 & 0,02 & 0,002 \\
\hline 1.3. & parkování & - & 0,03 & 1 & 0 & 1 & 1 & 1 & 0 & 0,03 & 0 \\
\hline 2.1. & Potraviny & $\mathrm{m}$ & 0,05 & 5 & 50 & 0 & 5 & 1 & 0,1 & 0,05 & 0,005 \\
\hline 2.2 . & Banky & $\mathrm{m}$ & 0,05 & 5 & 50 & 0 & 5 & 1 & 0,1 & 0,05 & 0,005 \\
\hline 2.3. & Pošta & $\mathrm{m}$ & 0,05 & 5 & 50 & 0 & 5 & 1 & 0,1 & 0,05 & 0,005 \\
\hline 2.4. & Pohostinství & $\mathrm{m}$ & 0,05 & 5 & 50 & 0 & 5 & 1 & 0,1 & 0,05 & 0,005 \\
\hline 3.1. & Novostavba & - & 0,5 & 0 & 1 & 1 & 1 & 0 & 1 & 0 & 0,5 \\
\hline 3.2. & Rekontrukce & - & 0,15 & 1 & 0 & 1 & 1 & 1 & 0 & 0,15 & 0 \\
\hline 4.1. & Vodovod & $\mathrm{m}$ & 0,01 & 0 & 5 & 0 & 0 & 1 & 0 & 0,01 & 0 \\
\hline 4.2. & Kanalizace & $\mathrm{m}$ & 0,01 & 0 & 5 & 0 & 0 & 1 & 0 & 0,01 & 0 \\
\hline 5.1. & Energetické sítě & $\mathrm{m}$ & 0,01 & 0 & 5 & 0 & 0 & 1 & 0 & 0,01 & 0 \\
\hline 5.2. & Plyn & $\mathrm{m}$ & 0,01 & 0 & 5 & 0 & 0 & 1 & 0 & 0,01 & 0 \\
\hline 5.3. & Teplá voda & $\mathrm{m}$ & 0,01 & 0 & 5 & 0 & 0 & 1 & 0 & 0,01 & 0 \\
\hline 6.1 . & Telekomukace & $\mathrm{m}$ & 0,01 & 0 & 5 & 0 & 0 & 1 & 0 & 0,01 & 0 \\
\hline 7.1. & Péče o zeleň & $\mathrm{m} 2$ & 0,01 & 0 & 20 & 0 & 0 & 1 & 0 & 0,01 & 0 \\
\hline 7.2. & Osvětlení & kus & 0,01 & 0 & 20 & 0 & 0 & 1 & 0 & 0,01 & 0 \\
\hline 7.3. & Technická zpráva komunikací & $\mathrm{m} 2$ & 0,01 & 0 & 5 & 0 & 0 & 1 & 0 & 0,01 & 0 \\
\hline
\end{tabular}

Vyhodnocení obou dvou pohledů, viz. Graf 1, vychází tak, jak je obecně známo. Z pohledu města je jednoznačně výhodné snižování počtu brownfield, zatímco pro investora je spiše výhodnější výstavba na zelené louce.

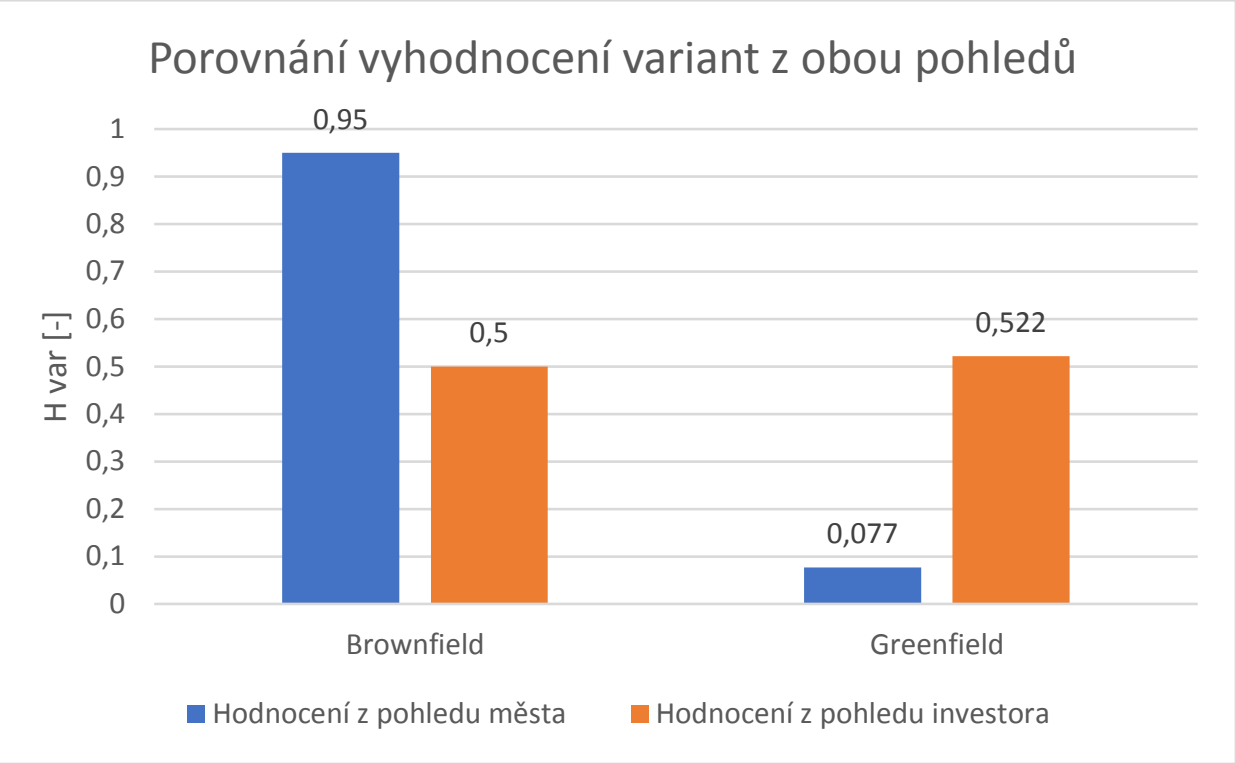

Graf 1: Porovnání vyhodnocení variant z pohledů investora a města. zdroj: vlastní 


\section{Porovnání změn pohledů investora a města na nový developerský projekt}

Pojetí investora na vybudování nového developerského projektu je jednoduchý, protože jeho hlavní kritérium je efektivnost. Jejímž cílem je zajištění, co možná nejvyšších zisků pro investora.

Zatímco jiný pohled je představitelů města, kteří jsou zodpovědní za jeho udržitelný rozvoj. Jak je blíže popsáno v kapitole 0 , str. 46 . Tak nové developerské projekty ve městech mají dopad na městské rozpočty. Při výstavbách na tzv. brownfieldech, nemají pro městský rozpočet téměř žádný dopad. $\mathrm{Na}$ rozdíl od toho výstavby na tzv. zelených loukách, mají pro městský rozpočet dopad negativní, jak při samotné výstavbě, tak jejím následném využívání. Což bylo názorně ukázáno v případě porovnání variant pro rozhodování v kapitolách 0 a 0.

$Z$ tohoto důvodu se snaží v současné době investoři prosazovat více možnosti výstavby na nových zelených loukách, protože nejsou př́liš ovlivněny okolní dispozicí a mají volné pole působnosti a mohou vhodněji navrhovat nejlevnější možné varianty. Města si většinou vůbec neuvědomují dopad těchto projektů na jejich rozpočet a může tak docházet ke zhoršování stavu měst z titulu zajištování potřebných nákladů z rozpočtu města, souvisejících se zabezpečením výstavby a provozu pro stavby na zelené louce

Jak je názorně ukázáno na Obr. 7 náklady investora a Graf 1 bývají téměř vždy nižší při výstavbě na tzv. zelených loukách. Zatímco, pro městský rozpočet je tento efekt právě opačný.

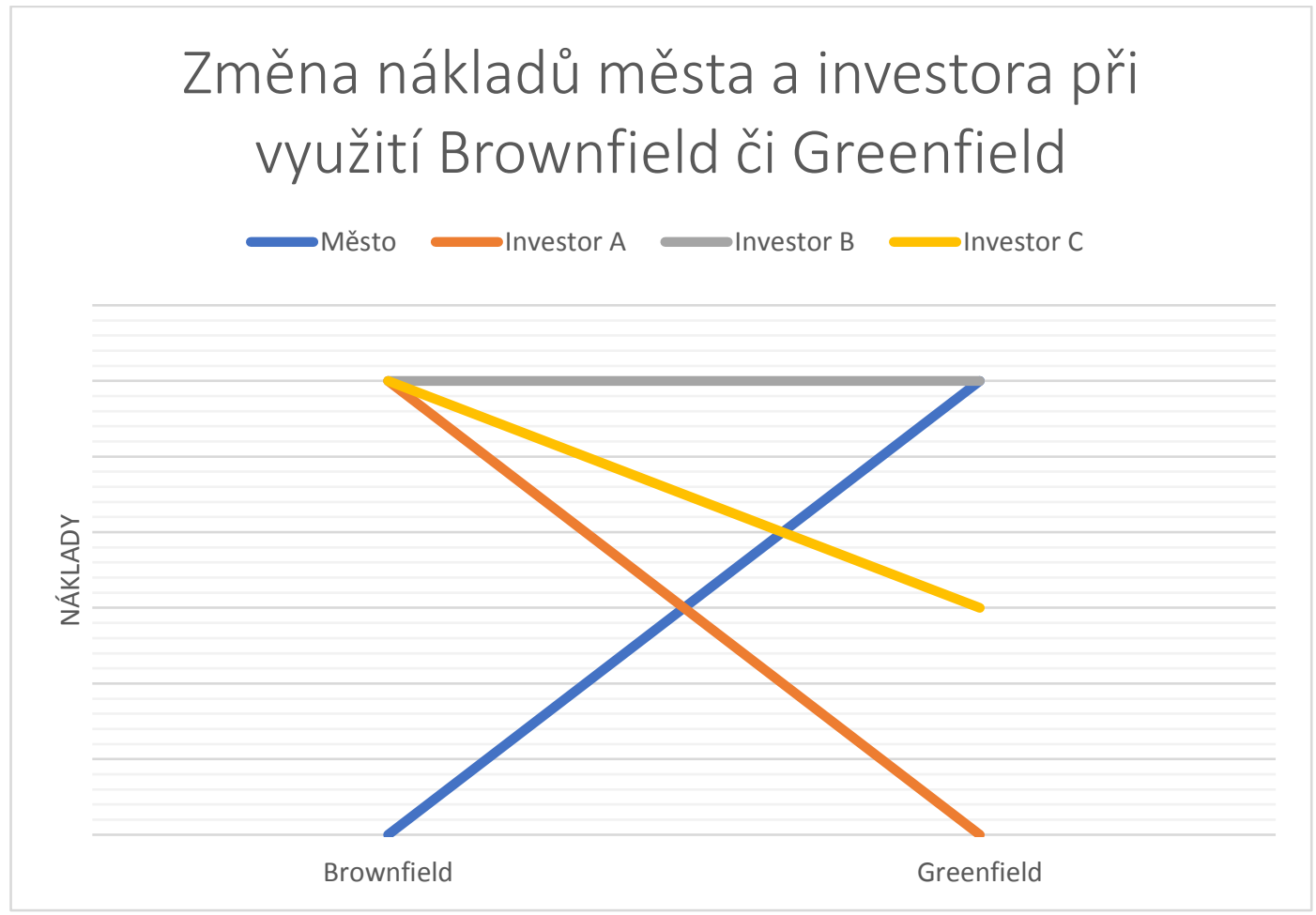

Obr. 7: Vliv nákladů při výstavbě brownfield a greenfield z pohledu města a investora, zdroj: vlastní 


\section{Závěr}

V současnosti Ize využívat velmi rozmanitý počet variant pro umistování staveb, a to v celé České republice. Výstupem bylo proto porovnat varianty výstavbovýho projeku z pohledu investora a města.

Byly definovány pozitivní a negativní vlivy na výstavbu nového projektu z hlediska města, jeho urbanistického řešení. Tam jednoznačně vyšla varianta brownfield jako výhodná. A to nejen ze strany úspor nákladů, ale také zatraktivnění oblasti jeho novým využitím.

Př́nos rozkladu jednotlivých činností městského inženýrství je obecným návodem pro rozhodování a k jeho naplnění nelze pohlížet jen z pohledu nákladů, ale celkové koncepce města, jeho intravilánu, jeho architektonické hodnoty okolních staveb a řady dalších faktorů. Tento fakt je zobrazen obecném př́stupu a ukázán v rozhodovacím procesu.

Obce se zatím tolik nezabývají problematikou městského inženýrství a možností snížení nákladů právě využitím brownfield. Většina obcí si ani nevede kategorizaci svých brownfieldů a nemůže tyto územní celky nabídnout potenciálním investorům.

Na problematiku brownfield a městskéhop inženýrství je potřeba upozornit. Zároveň upozornit na skutečnost, že je možné lépe využívat urbanistické přistupy v obcích.

Vzhledem k výsledkům z práce Ize upozornit na skutečnost nedostatečné informovanosti osob v České republice o problému brownfields. Existuje jediná databáze brownfield v České republice a to od společnosti Czechinvest, která tuto databázi vytvořila již před delší dobou a není bohužel úplná. Byla by ideální situace, kdyby jednotlivé obce, videálním př́padě, průběžné doplňovali jednotlivé brownfieldy do této databáze.

Tím, že není veřejně dostupná celá databáze brownfieldů, ovšem zabraňuje zrekonstruovat je a vytvárí se tím se tím menší možnost využívání ploch. Nyní Ize využívat spousty možností pro rozhodovací proces. $V$ této práce byla využita jedna z možných variant rozhodovacího procesu, a to metodou bazické varianty a upozorněno na možnost využití softwaru PREV. Pro využití bazické varianty je výhodou, že bylo-li by i v každé variantě ještě více variant čili zelená louka a různé alternativy architektonických řešení a u varianty brownfieldu, různé varianty využití stávajícího objektu nebo rozšiření tohoto objektu formou přístavby apod. Tak vlastně i pro tyto varianty je možné toto modelování s metodou bazické varianty využít. Jinak samožrejmě každá firma využívá své know-how $\mathrm{k}$ tomu jakým způsobem bude využívat svůj rozhodovací proces. Jak tu již bylo vícekrát rozhodnuto, tak je to jeden z nejdůležitějších procesů ve firmě. Může se jednat o osudové rozhodnutí, které bude stát celou firmu, potenciálně i město neskutečné peníze a může zajistit i krach neb o téměř nemožné oddlužení ze strany města.

Byli popsány a využity dva možné př́stupy k procesu rozhodování. Modelování probíhá s daty, která se dají získat od reálných řešení, to znamená vlastně údaje o tom, zdali bude stavba nová, bude-li umístněná na tzv. zelené louce. Budou potřebné nové př́stupové komunikace, nové napojení na sítě, ale i třeba i v budoucnu nové veřejné osvětlení, nová městská hromadná doprava apod. Každý z těchto přístupů má své pozitivní i negativní důsledky. Ideální je využít více rozhodovacích procesů, protože slouží k utvrzení dané strategie. Nýbrž jak bylo napsáno v této práci, tak proces rozhodování je subjektivní, a proto je potřeba nějakým způsobem dojít k objektivnějšímu výsledku a poradě k procesu.

V budoucnu by měla být snaha o zajištění snižování počtu brownfieldů v České republice. Jelikož je v této práci dokázano, že využívání těchto ploch pro výstavby a rekonstrukce, je pro městské rozpočty, potažmo státní rozpočet, velmi výhodné, měla by být snaha vytvořit dostatečné a lákavé dotační programy a dostatečnou informovanost veřejnosti o možnosti jejich získání. Jelikož je možné řady brownfieldů získat bez poplatku, tak se zároveň nabízí vytvořit jednotný právní předpis o převodu těchto nemovistostí do cizích rukou, za určitého předpokladu nakládání s tímto majetkem a dodržováním zásad, aby nezůstalo toto území brownfieldem i nadále. 


\section{Reference}

[1] Ministerstvo průmyslu a obchodu: Národní strategie regenerace brownfieldů. Praha, 2008. Dostupné také z: http://www.czechinvest.org/data/files/strategie-regenerace-vlada-1079.pdf

[2] Cabernet. Cabernet [online]. [cit. 2017-03-20]. Dostupné z: http://www.cabernet.org.uk/

[3] Brownfields příručka. In: Brownfields příručka [online]. [cit. 2017-04-17]. Dostupné z: https://fast10.vsb.cz/lepob/index2/handbook_cz_screen.pdf

[4] Wikipedie [online]. Praha: Wikipedie, 2017 [cit. 2017-04-17]. Dostupné z: https://cs.wikipedia.org/wiki/Greenfield

[5] Národní databáze brownfieldů. Národní databáze brownfieldů [online]. Praha: Czechinvest, 2008 [cit. 2017-04-25]. Dostupné z: http://www.brownfieldy.cz/informace-o-projektu/

[6] SEDLECKÝ, Jaroslav. Městský inženýr a městský architekt v roce 2017. In: Městské inženýrství Karlovy Vary 2017. Praha: Informační centrum ČKAIT, 2017, ISBN 978-80-87438-88-6.

[7] Český svaz stavebních inženýrů. Český svaz stavebních inženýrů [online]. Praha: CSSI, 2010 [cit. 201704-17]. Dostupné z: http://www.cssi-cr.cz

[8] ŠILHÁNKOVÁ, Vladimíra (2015). Urbanismus jako věda: historicko-lingvistické pojednání o pojetí urbanismu. In: HOLUBEC, Pavel, ed. Člověk, stavba a územní plánování 8. ČVUT v Praze, Fakulta stavební pp. 10-22. ISBN 978- 80-01-05655-4. ISSN 2336-7687.

[9] TOMÁNKOVÁ, Jaroslava a Dana ČÁPOVÁ. Management staveb. Praha: FinEco, 2013, 225 s. ISBN 9788086590127.

[10] PROSTĚJOVSKÁ, Zita. Řízení stavebních projektů: prezentace. Praha, 2015.

[11] SYNEK, M. Ekonomická analýza. 1.vyd. Praha: Vysoká škola ekonomická v Praze, 2003. ISBN 80-2450603-3,

[12] SCHNEIDEROVÁ HERALOVÁ, Renáta, BERAN, Václav a DLASK, Petr. Rozhodování: (vstupní data, významnost kritérií, hodnocení variant). Vyd. 1., Praha: České vysoké učení technické v Praze, 2011, 110 s. ISBN 978-80-01-04982-2

[13] DLASK, Petr a Václav BERAN. Software pro hodnocení projektů: PREV v. 2.0, Mosaic [online]. Praha: České vysoké učení technické v Praze, 2011 [cit. 2017-11-01]. ISBN 978-80-01-04880-1. 